\title{
The Impacts of Corporate Social Responsibility on Small and Medium Enterprises Performance
}

\author{
ESTI DWI RINAWIYANTI ${ }^{1}$, XUELI HUANG ${ }^{2}$, SHARIF AS-SABER ${ }^{3}$ \\ ${ }^{1}$ Study Program of Industrial Engineering, Faculty of Engineering, UNIVERSITY OF SURABAYA, INDONESIA, \\ E-mail: estidwi@staff.ubaya.ac.id \\ ${ }^{2}$ School of Management, COLLEGE OF BUSINESS AND LAW, RMIT UNIVERSITY, AUSTRALIA, \\ E-mail: charlie.huang@rmit.edu.au \\ ${ }^{3}$ School of Management, COLLEGE OF BUSINESS AND LAW, RMIT UNIVERSITY, AUSTRALIA, \\ E-mail: asia.family@gmail.com
}

\begin{abstract}
This study investigates how small and medium-sized enterprises (SMEs) conduct corporate social responsibility (CSR) and how it affects their performance. This study used quantitative research with data collected from 138 manufacturing SMEs in Java. By using partial least square structural equation modeling, this study discovers that economic and philanthropic responsibilities have a significant effect on customer and employee performances, whereas legal responsibility has a substantial impact on customer, employee, operational and financial performances. In contrast, ethical responsibility does not affect any aspect of company performance. The findings also highlight that legal responsibility is the most significant predictor of all four performances, and economic and philanthropic responsibilities are the second biggest predictors as each of them has a substantial effect on one performance. The results also show that customer and employee performances receive the most effect from two dimensions. Customer performance is significantly influenced by economic and legal responsibilities, while employee performance is significantly affected by legal and philanthropic responsibilities. These findings can encourage SMEs, particularly in developing countries, like Indonesia, to implement CSR beyond profit maximization and compliance to achieve higher social and financial performance.
\end{abstract}

Keywords: Business responsibility; CSR dimension; Developing countries; Employee performance; Manufacturing industry.

JEL Classification: C31, D2, G3, L6

Received: June 08, 2021

Accepted: October 01, 2021 


\title{
Las Repercusiones de la Responsabilidad Social de las Empresas en los Resultados de las Pequeñas y Medianas Empresas
}

\author{
ESTI DWI RINAWIYANTI ${ }^{1}$, XUELI HUANG ${ }^{2}$, SHARIF AS-SABER ${ }^{3}$ \\ ${ }^{1}$ Study Program of Industrial Engineering, Faculty of Engineering, UNIVERSITY OF SURABAYA, INDONESIA, \\ E-mail: estidwi@staff.ubaya.ac.id \\ ${ }^{2}$ School of Management, COLLEGE OF BUSINESS AND LAW, RMIT UNIVERSITY, AUSTRALIA, \\ E-mail: charlie.huang@rmit.edu.au \\ ${ }^{3}$ School of Management, COLLEGE OF BUSINESS AND LAW, RMIT UNIVERSITY, AUSTRALIA, \\ E-mail: asia.family@gmail.com
}

\begin{abstract}
RESUMEN
Este estudio investiga cómo las pequeñas y medianas empresas (PYMES) llevan a cabo la responsabilidad social corporativa (RSC) y cómo afecta a sus resultados. Este estudio utilizó una investigación cuantitativa con datos recogidos de 138 PYME manufactureras de Java. Mediante el uso de un modelo de ecuaciones estructurales de mínimos cuadrados parciales, este estudio descubre que las responsabilidades económicas y filantrópicas tienen un efecto significativo en los resultados de los clientes y los empleados, mientras que la responsabilidad legal tiene un impacto sustancial en los resultados de los clientes, los empleados, las operaciones y las finanzas. En cambio, la responsabilidad ética no afecta a ningún aspecto del rendimiento de la empresa. Los resultados también destacan que la responsabilidad legal es el predictor más significativo de los cuatro rendimientos, y las responsabilidades económicas y filantrópicas son los segundos mayores predictores, ya que cada uno de ellos tiene un efecto sustancial en un rendimiento. Los resultados también muestran que los rendimientos de los clientes y de los empleados son los que más efecto reciben de dos dimensiones. El rendimiento de los clientes está significativamente influenciado por las responsabilidades económicas y legales, mientras que el rendimiento de los empleados está significativamente afectado por las responsabilidades legales y filantrópicas. Estas conclusiones pueden animar a las PYME, sobre todo en los países en desarrollo, como Indonesia, a aplicar la RSE más allá de la maximización de los beneficios y el cumplimiento de las normas para lograr un mayor rendimiento social y financiero.
\end{abstract}

Palabras clave: Responsabilidad empresarial; Dimensión de la RSE; Países en desarrollo; Rendimiento de los empleados; Industria manufacturera.

Clasificación JEL: C31, D2, G3, L6 


\section{Introduction}

Corporate social responsibility (CSR) is a concept in which companies voluntarily incorporate social and environmental issues into their company operations and interaction with stakeholders (Commission, 2011). CSR should be defined as companies' ability to contribute to the development and progress of the communities in which they operate (Adeneye \& Ahmed, 2015). Companies, regardless of size, industry, or location, are concerned about CSR (Martinuzzi \& Krumay, 2013), and they aim to comply with and benefit from it (Razafindrambinina \& Sabran, 2014).

As most, CSR studies are concerned with examining the activities followed by companies in developed countries (Bai \& Chang, 2015; Zhu, Liu \& Lai, 2016). CSR is emerging as a distinct area of management studies in developing countries (Jamali \& Karam, 2018), including Indonesia. Therefore, it is essential to identify significant information on the contribution of CSR and the main factors affecting CSR performance (Blowfield, 2007; Crifo, Diaye, \& Pekovic, 2016).

With over 267 million people, Indonesia is the world's fourth most populated nation. As one of the biggest developing countries, Indonesia is the greatest economy in Southeast Asia (Worldbank, 2020). During the previous two decades, CSR has been getting more attention in Indonesia (Maris, 2014). Its government in 2007 released Law No. 40 regarding limited liability companies (UndangUndang No. 40 Tahun 2007 tentang Perseroan Terbatas) (Amrulloh, Sulastri, \& Firmansyah, 2020). With this law, Indonesia has become the world's first country that requires companies, particularly those involved in natural resources, to implement CSR and report those activities (Maris, 2014; Waagstein, 2011).

Practically, CSR is crucial for small and medium-sized enterprises (SMEs), not just big companies. The growth of SMEs, notably, is critical to the development of the Indonesian economy. Their existence could be a solution to lowering unemployment and accelerating local economic growth (Ratnawati, Soetjipto, Murwani, \& Wahyono, 2018).

Despite these significant advances and the shifting emphasis on CSR in emerging countries, how SMEs in these countries play a role in CSR has received less attention within the context of an extensive research agenda (Jamali, Lund-Thomsen, \& Jeppesen, 2017). There are also a few studies on CSR and multidimensional organizational performances in the context of Indonesian SMEs. Therefore, this study purposes to investigate CSR impacts on SMEs' performance to address these two research questions (RQ):

RQ1. Which dimension of CSR can affect organizational performance?

RQ2. Which performance is most affected by CSR?

The remainder of this paper is structured as follows: the theoretical background and the development of hypotheses are explained in the next section. The research method is then described, followed by the results and discussion. The final section presents the conclusion, including the contribution, practical implications, limitations and future studies recommendations.

\section{Literature Review}

\subsection{Stakeholder theory}

Stakeholders are groups and persons who can influence or are influenced by the accomplishment of a company's mission (Freeman 2010). As any business operation directly or indirectly affects stakeholders (Shital 2014), stakeholder theory contends that the company has obligations not just to shareholders but also to stakeholders (Freeman 2010). Primary stakeholders contain shareholders or investors, suppliers, employees, customers and the public stakeholder groups (i.e., governments and communities), whereas special interest groups and the media are secondary stakeholders (Clarkson, 1995).

In addition to stakeholders' contribution in accomplishing companies' objectives, they are a critical triggering factor for CSR implementation (Lane \& Devin, 2018; Zhu et al., 2016). In particular, 
CSR emphasizes how companies interact with internal and external stakeholders in an ethical, social, and responsible manner to enhance their living conditions while ensuring their profitability (Hopkins, 2005). CSR can benefit stakeholders, which improves company performance and reflects the organizational change results (Alsbaity, 2018).

\subsection{CSR dimension}

Consolidating the multiple views and economic and social perspectives, Carroll $(1979,1991)$ defines CSR as a multidimensional concept that includes economic, legal, ethical and philanthropic responsibilities. Accordingly, CSR can be classified into four dimensions as follows:

1. Economic responsibilities. The business has been conceptualized as an economic entity with its responsibility to produce and deliver goods and services as efficiently as possible while earning a reasonable profit.

2. Legal responsibilities. Businesses should comply with laws and regulations issued by governments as the fundamental guidelines under which they must operate.

3. Ethical responsibilities. Businesses should conduct their operations ethically by adhering to the standards, norms, or expectations that reflect a concern for what consumers, employees, shareholders and the community regard as fair or consistent with respecting or protecting the stakeholders' moral rights.

4. Philanthropic responsibilities or discretionary responsibilities. Philanthropy refers to corporate actions taken in response to societal expectations that businesses be good corporate citizens.

Carroll's classifications cover the entire range of societal obligations that businesses have (Garriga \& Melé, 2004) and have been recognized as comprehensive and integrative by many theorists and empirical researchers (Wang \& Berens, 2015). Maignan and Ferrell $(2000,2001)$ developed an instrument to evaluate CSR practices based on these classifications. Their instrument has been one of the most widely employed measurements in CSR studies (Dhanesh, 2014) and has been adopted in several studies examining the impact of CSR on organizational performance (Dhanesh, 2012; Kunda, Ataman, \& Behram 2019).

\subsection{Company performance}

Many studies have investigated the impacts of CSR on organizational performance. In terms of financial performance, companies can benefit more from consistent CSR engagement, such as reducing long-term financial problems and increasing sales growth, earnings before tax, and cash flows from operations (Ameer \& Othman, 2012; Frynas \& Yamahaki, 2016). Regarding non-financial performance, CSR can offer more efficient and better management operations (Aguinis \& Glavas, 2012; Malik, 2015). Furthermore, CSR can reinforce a company's human resources, increase employee loyalty and retention, foster employee productivity and boost customer loyalty (Aguinis \& Glavas, 2012; Malik, 2015; Mellahi, Frynas, Sun, \& Siegel, 2015; Moir, 2001). Based on these explanations, we suggest:

$\mathrm{H} 1$ : Economic responsibility significantly affects $(\mathrm{H} 1 \mathrm{a})$ customer performance, $(\mathrm{H} 1 \mathrm{~b})$ employee performance, $(\mathrm{H} 1 \mathrm{c})$ operational performance and $(\mathrm{H} 1 \mathrm{~d})$ financial performance.

$\mathrm{H} 2$ : Legal responsibility significantly affects ( $\mathrm{H} 2 \mathrm{a})$ customer performance, (H2b) employee performance, $(\mathrm{H} 2 \mathrm{C})$ operational performance and $(\mathrm{H} 2 \mathrm{~d})$ financial performance.

H3: Ethical responsibility significantly affects ( $\mathrm{H} 3 \mathrm{a}$ ) customer performance, (H3b) employee performance, $(\mathrm{H} 3 \mathrm{C})$ operational performance and $(\mathrm{H} 3 \mathrm{~d})$ financial performance.

$\mathrm{H} 4$ : Philanthropic responsibility significantly affects ( $\mathrm{H} 4 \mathrm{a}$ ) customer performance, ( $\mathrm{H} 4 \mathrm{~b})$ employee performance, $(\mathrm{H} 4 \mathrm{C})$ operational performance and $(\mathrm{H} 4 \mathrm{~d})$ financial performance. 


\section{Methodology}

\subsection{CSR dimensions}

CSR measurement items were modified from Maignan and Ferrell $(2000,2001)$ that consisted of four dimensions (constructs): economic, legal, ethical and philanthropic responsibilities. Respondents rated their responses with a five-point scale from $1=$ "strongly disagree" to $5=$ " strongly agree" (see Table 1).

Table 1 CSR measurement items

\begin{tabular}{|c|c|c|c|c|c|c|}
\hline \multicolumn{2}{|r|}{ Dimension (construct) and item (indicator) } & Mean & SD & Loading & \multirow{3}{*}{$\begin{array}{l}\text { AVE } \\
0.55\end{array}$} & \multirow{2}{*}{$\begin{array}{c}\text { Cronbach's } \\
\text { alpha } \\
0.73\end{array}$} \\
\hline & Economic responsibility (Economic) & & & & & \\
\hline CS01 & We seek to reduce our operating costs. & 4.01 & 0.96 & & & \\
\hline CS02 & We thoroughly monitor employee productivity. & 4.10 & 0.83 & 0.66 & & \\
\hline CS03 & Top management develops long-term strategies. & 4.14 & 0.82 & 0.76 & & \\
\hline CS04 & $\begin{array}{l}\text { We establish a procedure to handle customer } \\
\text { complaints. }\end{array}$ & 4.04 & 0.81 & 0.77 & & \\
\hline CS05 & We constantly improve our product quality. & 4.42 & 0.76 & 0.77 & & \\
\hline CS06 & $\begin{array}{l}\text { Legal responsibility (Legal) } \\
\text { Internal policies prevent discrimination in } \\
\text { employee's compensation and promotion. }\end{array}$ & 3.96 & 0.84 & 0.74 & 0.61 & 0.84 \\
\hline CS07 & $\begin{array}{l}\text { We strive to follow all laws governing hiring and } \\
\text { employee benefits. }\end{array}$ & 4.15 & 0.75 & 0.82 & & \\
\hline CS08 & Our products fulfill legal standards. & 4.32 & 0.82 & 0.85 & & \\
\hline CS09 & $\begin{array}{l}\text { Our contractual obligations are always } \\
\text { honoured. }\end{array}$ & 4.35 & 0.70 & 0.77 & & \\
\hline CS10 & Managers know relevant environmental laws. & 4.06 & 0.70 & 0.63 & & \\
\hline & Ethical responsibility (Ethical) & & & & 0.58 & 0.82 \\
\hline CS11 & We establish a comprehensive code of conduct. & 4.06 & 0.77 & 0.79 & & \\
\hline CS12 & We are well-known for being a reliable company. & 4.33 & 0.87 & 0.72 & & \\
\hline CS13 & $\begin{array}{l}\text { The employee evaluation process considers } \\
\text { fairness to coworkers and business partners. }\end{array}$ & 4.17 & 0.76 & 0.76 & & \\
\hline CS14 & $\begin{array}{l}\text { We have an appropriate procedure for } \\
\text { employees to report any workplace misconduct. }\end{array}$ & 3.91 & 0.83 & 0.87 & & \\
\hline CS15 & Our employees follow professional standards. & 3.99 & 0.85 & 0.76 & & \\
\hline Discre & tionary/philanthropic responsibility (Philanthropic) & & & & 0.52 & 0.78 \\
\hline CS16 & We provide adequate charitable contributions. & 3.75 & 0.95 & 0.77 & & \\
\hline CS17 & $\begin{array}{l}\text { We encourage partnerships with local } \\
\text { businesses and schools. }\end{array}$ & 3.64 & 1.01 & 0.72 & & \\
\hline CS18 & We contribute to sports and/or cultural activities. & 3.20 & 1.05 & 0.75 & & \\
\hline CS19 & $\begin{array}{l}\text { We implement a program to reduce the amount } \\
\text { of energy and materials wasted. }\end{array}$ & 3.79 & 0.83 & 0.67 & & \\
\hline CS20 & $\begin{array}{l}\text { We encourage employees to participate in civic } \\
\text { organizations that benefit our community. }\end{array}$ & 3.41 & 1.01 & 0.70 & & \\
\hline
\end{tabular}

\subsection{Company performance measurements}

There was a lack of reliable, objective measurements of the Indonesian SMEs surveyed and their unwillingness to disclose business performance information. This study thus used subjective measures by asking respondents to rate their business performance over the last three years compared to their competitors (Richard \& Marilyn, 2006; Wall et al., 2004).

CSR, manufacturing and strategic management literature were used to develop measurement items of company performance. Respondents were required to rate their responses using a fivepoint scale from 1=" much longer/much lower/much worse" to $5="$ much shorter/much higher/much better" (see Table 2). 
Table 2 Company performance measurement items

\begin{tabular}{|c|c|c|c|c|c|c|c|c|}
\hline \multicolumn{2}{|c|}{$\begin{array}{l}\text { Dimension (construct) and item } \\
\text { (indicator) }\end{array}$} & Mean & SD & Loading & AVE & $\begin{array}{l}\text { Cronbach' } \\
\text { s alpha }\end{array}$ & $\begin{array}{c}\mathbf{R}^{2} \\
\text { value }\end{array}$ & $\begin{array}{c}\mathbf{Q}^{2} \\
\text { value }\end{array}$ \\
\hline \multicolumn{2}{|c|}{ Customer performance (CCP) } & & & & 0.72 & 0.81 & 0.14 & 0.07 \\
\hline CP11 & Customer complaints & 2.35 & 0.94 & & & & & \\
\hline CP12 & Customer satisfaction & 4.00 & 0.72 & 0.93 & & & & \\
\hline CP13 & Customer loyalty & 4.12 & 0.74 & 0.90 & & & & \\
\hline CP14 & $\begin{array}{l}\text { An increasing number of } \\
\text { consumers }\end{array}$ & 3.72 & 0.75 & 0.70 & & & & \\
\hline \multicolumn{2}{|c|}{ Employee performance (CEP) } & & & & 0.67 & 0.76 & 0.38 & 0.24 \\
\hline CP04 & Training of employee & 3.56 & 0.76 & 0.84 & & & & \\
\hline CP05 & Career opportunities & 3.64 & 0.75 & 0.85 & & & & \\
\hline CP15 & Employee motivation & 3.62 & 0.72 & 0.76 & & & & \\
\hline CP16 & Employee turnover & 2.70 & 1.02 & & & & & \\
\hline \multicolumn{2}{|c|}{ Financial performance (CFP) } & & & & 0.58 & 0.75 & 0.12 & 0.06 \\
\hline CP03 & Cash flow report & 3.64 & 0.74 & 0.66 & & & & \\
\hline CP08 & Profit & 3.65 & 0.74 & 0.80 & & & & \\
\hline CP09 & $\begin{array}{l}\text { Return on investment } \\
\text { (ROI) }\end{array}$ & 3.59 & 0.74 & 0.86 & & & & \\
\hline \multirow[t]{2}{*}{ CP10 } & Sales growth & 3.74 & 0.80 & 0.70 & & & & \\
\hline & $\begin{array}{l}\text { Operational performance } \\
\text { (COP) }\end{array}$ & & & & 0.60 & 0.71 & 0.10 & 0.03 \\
\hline СР01 & $\begin{array}{l}\text { Timeline of customer } \\
\text { service }\end{array}$ & 3.86 & 0.78 & 0.75 & & & & \\
\hline CP02 & Delivery time & 3.86 & 0.78 & 0.72 & & & & \\
\hline CP06 & Productivity & 3.92 & 0.71 & 0.83 & & & & \\
\hline CP07 & Operational efficiency & 3.80 & 0.71 & 0.79 & & & & \\
\hline
\end{tabular}

\subsection{Sample and data collection}

Apart from being the largest contributor to Indonesia's manufacturing industry with more than $70 \%$ of Indonesia's GDP (Agustinus, 2017), Java also has $64.29 \%$ or 4.41 million manufacturing companies (BPS, 2017). Accordingly, this study took manufacturing companies in Java as a sample study, covering five regions, i.e., Jakarta, West Java, Yogyakarta, Central Java and East Java. The sample study included 33 sets of the Indonesian Standard Industrial Classification. It involved company categories by the Indonesian Central Bureau of Statistics; that is, small (5-19 employees), medium (20-99 employees) and large (over 100 employees).

This study employed a self-completion survey via mail, online and personal delivery. Overall, questionnaires were distributed to 1,055 manufacturing companies from June to October 2018. After the data screening of 514 returned questionnaires, 435 responses remained in the data set, and 138 were SMEs, presented in this paper.

The possibility of a common method bias as a potential issue from using a single informant when gathering data was evaluated in two ways (Hulland, Baumgartner, \& Smith, 2018; Podsakoff, MacKenzie, Jeong-Yeon, \& Podsakoff, 2003). First, the respondents were assured of anonymity; thus, neither their companies nor personal information could be traced to them (Podsakoff et al., 2003). Second, this study conducted Harman's one-factor test involving 36 variables in principal component analysis (PCA) (Kock, 2015; Podsakoff et al., 2003). In doing so, PCA yielded nine distinct factors, representing a total variance of $67.18 \%$. A single factor presented the highest portion of the variance (27.69\%). This result indicated that this study contained no common method bias.

\section{Results and Discussion}

\subsection{Descriptive analysis}

Concerning the respondents' profiles, most respondents are between the ages of 41 and 60 (53.6\%). One-third of respondents (32.6\%) is from 25 to 40 years of age. The remaining $8.7 \%$ are under 25 , whereas $5.1 \%$ are above 60 years of age. More than half of the respondents $(60.14 \%)$ are 
in the top management position (owner and director), and one-third (31.16\%) are in the management position (assistant, middle and senior manager). The remaining $8.7 \%$ consists of team leaders and others. Most respondents (39.9\%) have over 10 years of work experience, $34.8 \%$ have less than five years, while $25.4 \%$ have six to 10 years of work experience.

Samples from a variety of manufacturing SMEs were selected. The main products of respondents' companies are: 1) food and beverage $(32.6 \%), 2)$ textiles $(14.5 \%), 3)$ rubber and plastic products $(7.2 \%), 4)$ fabricated metal products $(7.2 \%)$ and 5 ) chemicals and chemical products $(5.8 \%)$. Food and beverages, textiles, and chemicals and chemical products were three of the five products that contributed the most to the manufacturing sector's export value in 2019. (Kemenperin, 2020). As a result, the sample may represent the population of manufacturing SMEs in Indonesia.

More than half of respondents' companies (59.4\%) have been operating between 11 and 50 years, and $22.5 \%$ have run their business for five to 10 years. The remaining $16.7 \%$ have operated for less than five years, and $1.4 \%$ have worked for over 50 years. Most respondents' companies (79.71\%) are in East Java, $12.32 \%$ are in Centre Java and Yogyakarta, while $7.97 \%$ are in West Java and Jakarta.

Table 1 shows that 12 variables have mean values above 4.0. Among four dimensions, legal responsibility has the biggest mean value of 4.17 , followed by economic responsibility (4.14) and ethical responsibility (4.09). Philanthropic responsibility has the lowest mean value of 3.56 . Regarding company performance, 12 variables have mean values between 3.0 and 4.0 (see Table 2). COP has the highest mean value (3.86), followed by CFP (3.66) and CCP (3.55). On the other hand, CEP has the smallest mean value (3.38).

\subsection{PLS-SEM analysis}

This study analyzed data using PLS-SEM for two reasons. First, PLS-SEM is appropriate in predicting which dimension of CSR has the most significant impact on organizational performance (Hair, Hult, Ringle, \& Sarstedt, 2017; Matthews, Hair, \& Matthews, 2018). Second, PLS-SEM can accommodate the data distribution abnormality found in the data set (Hair et al., 2017).

Figure 1 depicts a model of the relationship between four dimensions of CSR and four aspects of company performance. SmartPLS 3 was employed to assess the measurement and structural models. The PLS algorithm used the weighting scheme of factor, maximum iterations of 500, and stop criterion of 7. With the 'no sign changes' option in the original data, the bootstrapping procedure ran 5,000 subsamples and 500 observations. In addition, for the confidence interval method, two-tailed testing with a significance level of 0.05 , complete bootstrapping, bias-corrected and accelerated (BCa) bootstrap were used (Hair et al., 2017; Hair, Sarstedt, Ringle, \& Gudergan, 2018).

\section{Assessment of measurement model}

As shown in Table 1 and Table 2, reflective measures have Cronbach's alpha from 0.74 to 0.84 , above 0.70 and below 0.90 (Hair et al., 2017). Indicators' loadings are above 0.70 and significant. Except for CS01, CP11, and CP16, they were eliminated because their loadings were less than 0.50 . The Fornell-Larcker criterion is the most widely used conservative approach to testing discriminant validity (Hair et al., 2017; Hamid, Sami, \& Sidek, 2017). Except for the Economic-Ethic construct, which has a similar value, the square root of average variance extracted (AVE) is higher than the cross-loadings with other constructs. Overall, the result revealed that the assessment of measurement models has been achieved satisfactorily. 
Figure 1 The model of CSR-company performance relationship

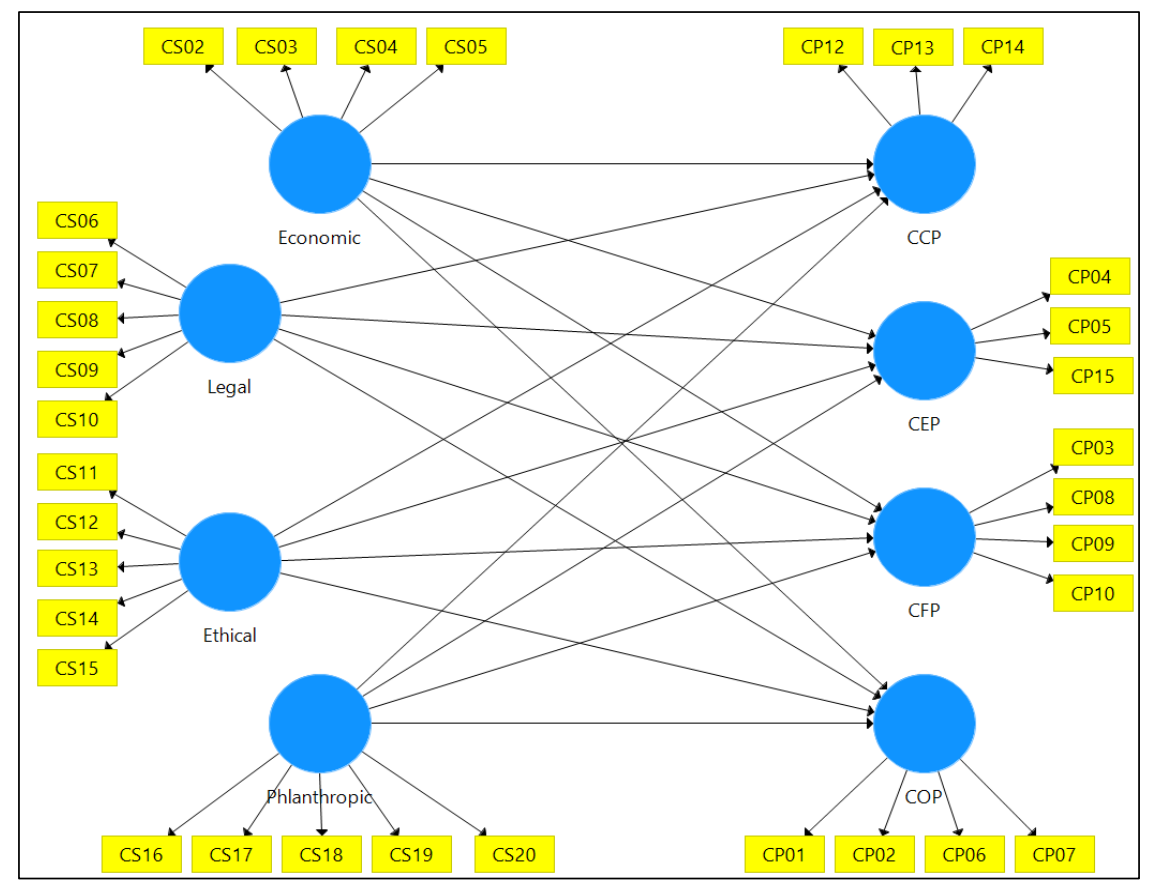

\section{Assessment of structural model}

Regarding the determination coefficient, the most significant predictor of the structural model is CEP $\left(R^{2}=0.38\right)$, followed by CCP $\left(R^{2}=0.14\right)$ and CCP $\left(R^{2}=0.12\right)$, and then COP $\left(R^{2}=0.10\right)$ (see Table 2$)$. Philanthropic has a significant medium effect on CEP $\left(f^{2}=0.09\right)$ at the $10 \%$ confidence level. The resulting cross-validated redundancies $\left(\mathrm{Q}^{2}\right)$ are in the range of 0.03 to 0.24 . Accordingly, the four exogenous constructs of CSR have a medium predictive relevance on four endogenous constructs.

As presented in Table 3, 16 direct effects from CSR to company performance. Three positive and significant relationships are: Economic $>\operatorname{CCP}(\beta=0.28, p<0.05)$, Legal $\rightarrow \operatorname{CEP}(\beta=0.28, p<0.05)$ and Philanthropy $>$ CEP $(\beta=0.30, p<0.05)$. At the confidence level of $10 \%$, three paths have a significant direct effect: Legal $->\operatorname{CCP}((\beta=0.18, p<0.10)$, Legal $->\operatorname{COP}(\beta=0.25, p<0.10)$, and Legal $->\operatorname{CFP}(\beta=0.2$, $p<0.10)$. Surprisingly, there are no significant direct effects from Ethical to CCP, CEP, COP and CFP.

The result indicates that economic responsibility has a significant impact on $\mathrm{CCP}$, which supports $\mathrm{H} 1 \mathrm{a}$. Interestingly, legal responsibility directly affects $\mathrm{CCP}, \mathrm{CEP}$, and COP, supporting H3a, H3b, H3c and $\mathrm{H} 3 \mathrm{~d}$. Philanthropic responsibility has a significant impact on CEP, supporting $\mathrm{H} 4 \mathrm{~b}$ accordingly.

There is a plausible explanation for these findings. When SMEs conduct their businesses economically in compliance with the regulations, it will positively impact their essential primary external stakeholder by enhancing customer satisfaction, improving customer loyalty and generating more customers. These findings are consistent with results from other studies. CSR would have an immense effect on the perceptions and attitudes of customers towards companies and the goods they manufacture (Nguyen, Vo, Nguyen, \& Choo, 2020). CSR also affects customer loyalty and customer satisfaction (Awatara, Samsi, Hamdani, \& Susila, 2020).

Furthermore, fulfilling the legal and philanthropic responsibilities can reflect a company's commitment to comply with regulations and concern the community. The findings show that SMEs can achieve better employee performance by providing appropriate training for their employees, offering them good career opportunities, and thus, increasing employee motivation. Employees who work for more dedicated employers tend to be more optimistic, loyal, and productive (Dey \& Sircar, 2012). If employees are sufficiently motivated, they will complete their works with perseverance (Uloli, Akbar, \& Kadir, 2019). Besides, if they believe that their companies are socially responsible for legal problems, they are more likely to trust them (Kunda, Ataman, \& Behram, 2019). As a result, 
they can produce better operational performance (Sun \& Yu, 2015), whereas improved employee performance can lead to a good company reputation (Aziz et al., 2020).

Table 3 Direct effect

\begin{tabular}{|c|c|c|c|c|c|}
\hline Hypothesis & Path & Direct effect & t-value & $p$-value & Supported? \\
\hline $\mathrm{H} 1 \mathrm{a}$ & Economic -> CCP & $0.28[0.06,0.50]$ & 2.09 & 0.02 & Yes \\
\hline $\mathrm{H} 1 \mathrm{~b}$ & Economic -> CEP & $0.00[-0.15,0.15]$ & 0.04 & 0.48 & No \\
\hline $\mathrm{H} 1 \mathrm{c}$ & Economic -> COP & $0.13[-0.10,0.38]$ & 0.92 & 0.18 & No \\
\hline $\mathrm{H} 1 \mathrm{~d}$ & Economic -> CFP & $0.13[-0.09,0.36]$ & 0.95 & 0.17 & No \\
\hline $\mathrm{H} 2 \mathrm{a}$ & Ethical -> CCP & $-0.08[-0.31,0.16]$ & 0.52 & 0.30 & No \\
\hline $\mathrm{H} 2 \mathrm{~b}$ & Ethical -> CEP & $0.14[-0.07,0.33]$ & 1.11 & 0.13 & No \\
\hline $\mathrm{H} 2 \mathrm{c}$ & Ethical -> COP & $-0.10[-0.38,0.18]$ & 0.61 & 0.27 & No \\
\hline $\mathrm{H} 2 \mathrm{~d}$ & Ethical -> CFP & $-0.06[-0.29,0.16]$ & 0.47 & 0.32 & No \\
\hline H3a & Legal -> CCP & $0.18[-0.05,0.40]$ & 1.31 & 0.09 & Yes \\
\hline H3b & Legal -> CEP & $0.28[0.11,0.46]$ & 2.67 & 0.00 & Yes \\
\hline $\mathrm{H} 3 \mathrm{c}$ & Legal -> COP & $0.25[-0.03,0.51]$ & 1.51 & 0.07 & Yes \\
\hline H3d & Legal -> CFP & $0.26[-0.03,0.50]$ & 1.58 & 0.06 & Yes \\
\hline $\mathrm{H} 4 \mathrm{a}$ & Philanthropy -> CCP & $0.03[-0.14,0.21]$ & 0.26 & 0.40 & No \\
\hline $\mathrm{H} 4 \mathrm{~b}$ & Philanthropy -> CEP & $0.30[0.17,0.43]$ & 3.74 & 0.00 & Yes \\
\hline $\mathrm{H} 4 \mathrm{c}$ & Philanthropy -> COP & $0.12[-0.07,0.32]$ & 1.00 & 0.16 & No \\
\hline $\mathrm{H} 4 \mathrm{~d}$ & Philanthropy -> CFP & $0.03[-0.15,0.23]$ & 0.22 & 0.41 & No \\
\hline
\end{tabular}

Moreover, when CSR is conducted in compliance with obligations (Amrulloh et al., 2020), SMEs can ensure their stakeholders that they operate their activities and create the financial report legally. This condition is conducive to improving operational performance (e.g., shorter customer service timeline, increased productivity, faster delivery time and improved operational efficiency). It can also enhance financial performance, such as better cash flow report, greater profit, higher sales growth and ROI.

The findings of this study reveal that only three CSR dimensions (i.e., economic, legal, and philanthropic responsibilities) have a significant impact on company performance. On the contrary, the ethical dimension has no effect on any performance. The findings are supported by a prior study that not all CSR dimensions have an equally significant effect on organizational commitment (Dhanesh, 2012). However, the findings of this study differ from another finding, suggesting that the ethical dimension has the most significant influence on employee performance (Peterson, 2004). In this study, employee performance is most affected by legal and philanthropic responsibilities, and customer performance is influenced by economic and legal responsibilities. This finding is supported by other findings from prior studies. Involvement of all stakeholders is essential in decision-making, such as CSR practices (Alsbaity, 2018), while employee and customer (in addition to the environment) are the most critical stakeholders for SMEs (Jain, Vyas, \& Chalasani, 2016). Accordingly, SMEs should maintain a reliable and beneficial relationship with their primary stakeholders. If the company has a better relationship with stakeholders, it will be easier to achieve its business objectives. However, if the company has a poor relationship with stakeholders, achieving its objectives will be more difficult (Maulamin, 2017).

In summary, RQ1 asks which dimension of CSR can affect company performance. The findings reveal that legal responsibility is the CSR dimension with the highest mean value and the most significant predictor of four performances. Economic and philanthropic responsibilities are the second most significant predictors because they have a substantial effect on one performance. Conversely, ethical responsibility has no effect on any performance. RQ2 inquires as to which performance is most influenced by CSR dimensions. The findings suggest that two dimensions have the most significant influence on customer and employee performance. Customer performance is influenced significantly by economic and legal responsibilities, while employee performance is 
affected significantly by legal and philanthropic responsibilities. Employee performance, however, has the greatest impact of the two.

\section{Conclusion}

This study evaluates the model that describes the relationship between four CSR dimensions and company performance. The findings reveal that six of 16 hypotheses were supported. This study highlights that three CSR dimensions (economic, legal and philanthropic responsibilities) significantly affect social and financial companies' performance. The findings discover that legal responsibility is the primary driving factor of CSR practices in the Indonesian context. As a result, it is relevant that manufacturing companies are affected by CSR regulation (Laws No. 40 in 2007).

The findings of this study enrich CSR literature by elucidating how CSR can be implemented and how it impacts organizational performance. The findings provide empirical evidence that primary stakeholders (e.g., customer and employee) should be considered in CSR implementation and organizational performance analysis.

Besides, the findings of this study have implications for SMEs, particularly in developing countries. The findings can help SMEs conduct CSR by improving their understanding of the various CSR activities. Importantly, the findings can motivate SMEs to implement CSR beyond profit-oriented motivations and legal enforcement. The results suggest that they can achieve better employee performance by engaging in philanthropic activities.

This study, however, has some limitations. First, this study counted on the data collected from respondents as single informants. Future studies may address this concern by involving many levels of informants, for example combining customer and employee surveys for better data distribution and bias reduction. Second, because this study focused on a single industry in Java, the findings of this study could limit the generalizability. Future studies could overcome this limitation by integrating other sectors and regions, such as the service industry inside and outside Java.

\section{Acknowledgments}

The first author (EDR) would like to thank the Indonesian Endowment Fund for Education (LPDP), Ministry of Finance, collaborated with the Directorate General of Higher Education (DIKTI), Ministry of Research, Technology and Higher Education, Republic of Indonesia, for supporting this study financially.

\section{References}

1. Adeneye, Y. B. \& Ahmed, M. (2015). Corporate Social Responsibility and Company Performance, Journal of Business Studies Quarterly, 7(1), 151-166.

2. Aguinis, H., \& Glavas, A. (2012). What We Know and Don't Know About Corporate Social Responsibility. Journal of Management, 38(4), 932-968.

3. Agustinus, M. (2017). 99\% Indonesian manufacturers are small business. Retrieved February 2, 2018 from https://finance.detik.com/industri/d-3485556/99-industri-pengolahan-di-ri-berskalakecil.

4. Alsbaity, M. A. (2018). Stakeholders Theoryand Its effects on Organization'sTechnological Change. International Journal of Accounting \& Finance in Asia Pasific, 1(1), 1-44.

5. Ameer, R., \& Othman, R. (2012). Sustainability Practices and Corporate Financial Performance: A Study Based on the Top Global Corporations. Journal of Business Ethics, 108(1), 61-79.

6. Amrulloh, D., Sulastri, S. \& Firmansyah, R. (2020). The Meaning of Corporate Social Responsibility (CSR): A Phenomenological Study in PT. Sejahtera Usaha Bersama Jombang. International Journal of Accounting Finance in Asia Pacific, 3(2), 37-45. 
7. Awatara, I. G. P. D., Samsi, S., Hamdani, A. \& Susila, L. N. (2020). The Influence of Corporate Social Responsibilty, Reputation, and Customer Satisfaction Towards Tourism Loyalty on Karanganyar Regency. Journal of International Conference Proceedings, 3(1), 291-296.

8. Aziz, A., Kee, D. M. H., Danieal, D., Azmi, M., Firdaus, M., Alkhalaf, L., \& Tripathi, A. (2020). Corporate Social Responsibility and Citizenship Behaviour: A Case Study of Dell. Journal of The Community Development in Asia, 3, 16-24.

9. Bai, X. \& Chang, J. (2015). Corporate social responsibility and firm performance: The mediating role of marketing competence and the moderating role of market environment. Asia Pacific Journal of Management, 32(2), 505-530.

10.Blowfield, M. (2007). Reasons to be cheerful? What we know about csr's impact. Third World Quarterly, 28(4), 683-695. doi:10.1080/01436590701336523

11.BPS (2017). Aglomeration of Indonesian manufacturing industry. Badan Pusat Statistik, Indonesia, 978-602-438-178-3.

12.Carroll, A. B. (1979). A Three-Dimensional Conceptual Model of Corporate Performance. The Academy of Management Review, 4(4), 497-505.

13.Carroll, A. B. (1991). The pyramid of corporate social responsibility: Toward the moral management of organizational stakeholders. Business Horizons, 34(4), 39-48. doi:http://dx.doi.org/10.1016/0007-6813(91)90005-G

14.Clarkson, M. B. E. (1995). A Stakeholder Framework for Analyzing and Evaluating Corporate Social Performance. Academy of Management. The Academy of Management Review, 20(1), 92.

15.Commission, E. (2011). Communication From The Commission To The European Parliament, The Council, The European Economic And Social Committee And The Committee Of The Regions: A Renewed EU Strategy 2011-14 For Corporate Social Responsibility.

16.Crifo, P., Diaye, M.-A., \& Pekovic, S. (2016). CSR related management practices and firm performance: An empirical analysis of the quantity-quality trade-off on French data. International Journal of Production Economics, 171, Part 3, 405-416.

17.Dhanesh, G. S. (2012). The view from within: internal publics and CSR. Journal of Communication Management, 16(1), 39-58.

18.Dhanesh, G. S. (2014). CSR as Organization-Employee Relationship Management Strategy: A Case Study of Socially Responsible Information Technology Companies in India. Management Communication Quarterly, 28(1), 130-149.

19.Dey, M., \& Sircar, S. (2012). Integrating Corporate Social Responsibility Initiatives with Business Strategy: A Study of Some Indian Companies. IUP Journal of Corporate Governance, 11(1), 36-51.

20.Freeman, R. E. (2010). Strategic Management: A Stakeholder Approach. New York: Cambridge University Press.

21.Frynas, J. G., \& Yamahaki, C. (2016). Corporate social responsibility: review and roadmap of theoretical perspectives. Business Ethics: A European Review, 25(3), 258-285. doi:10.1111/beer.12115

22.Garriga, E., \& Melé, D. (2004). Corporate Social Responsibility Theories: Mapping the Territory. Journal of Business Ethics, 53(1), 51-71. doi:10.1023/b:busi.0000039399.90587.34

23.Hair, J., Hult, G., Ringle, C. M., \& Sarstedt, M. (2017). A primer on partial least squares structural equation modeling (PLS-SEM) (Second ed.). Los Angeles: Sage.

24.Hair, J., Sarstedt, M., Ringle, C. M., \& Gudergan, S. P. (2018). Advanced Issues in Partial Least Squares Structural Equation Modeling. United States of America: Sage Publications Inc.

25.Hamid, M. R. A., Sami, W., \& Sidek, M. H. M. (2017). Discriminant Validity Assessment: Use of Fornell \& Larcker criterion versus HTMT Criterion. Journal of Physics: Conf. Series, 890, 1-5. doi:10.1088/1742-6596/890/1/012163 
26. Hopkins, M. (2005). Measurement of corporate social responsibility. International Journal of Management and Decision Making, 6(3-4), 213-231.

27.Hulland, J., Baumgartner, H., \& Smith, K. M. (2018). Marketing survey research best practices: evidence and recommendations from a review of JAMS articles. Journal of the Academy of Marketing Science, 46(1), 92-108. doi:10.1007/s11747-017-0532-y

28.Jain, P., Vyas, V. \& Chalasani, D. P. S. (2016). Corporate Social Responsibility and Financial Performance in SMEs: A Structural Equation Modelling Approach. Global Business Review, 17(3), 630-653.

29.Jamali, D., \& Karam, C. (2018). Corporate Social Responsibility in Developing Countries as an Emerging Field of Study. International Journal of Management Reviews, 20(1), 32-61. doi:10.1111/ijmr.12112

30.Jamali, D., Lund-Thomsen, P., \& Jeppesen, S. (2017). SMEs and CSR in Developing Countries. Business \& Society, 56(1), 11-22. doi:10.1177/0007650315571258

31.Kemenperin (2020). Industri Pengolahan Jadi Andalan Ekspor Nasional. Retrieved April 7, 2020 from https://kemenperin.go.id/artikel/21409/Industri-Pengolahan-Jadi-Andalan-Ekspor-Nasional.

32.Kock, N. (2015). Common method bias in PLS-SEM: A full collinearity assessment approach. International Journal of e-Collaboration, 11(4), 1-10.

33.Kunda, M. M., Ataman, G., \& Behram, N. K. (2019). Corporate Social Responsibility and Organizational Citizenship Behavior: The Mediating Role of Job Satisfaction. Journal of Global Responsibility, 10(1), 47-68. doi:http://dx.doi.org/10.1108/JGR-06-2018-0018

34.Lane, A. B., \& Devin, B. (2018). Operationalizing Stakeholder Engagement in CSR: A Process Approach. Corporate Social Responsibility and Environmental Management, 25(3), 267-280. doi:10.1002/csr.1460

35.Maignan, I., \& Ferrell, O. C. (2000). Measuring Corporate Citizenship in Two Countries: The Case of the United States and France. Journal of Business Ethics, 23(3), 283-297.

36.Maignan, I., \& Ferrell, O. C. (2001). Antecedents and benefits of corporate citizenship: an investigation of French businesses. Journal of Business Research, 51(1), 37-51.

37. Malik, M. (2015). Value-Enhancing Capabilities of CSR: A Brief Review of Contemporary Literature. Journal of Business Ethics, 127(2), 419-438. doi:10.1007/s10551-014-2051-9

38. Maris, A. (2014). Compulsory CSR: Indonesia takes a tough stance but clarity on definitions is lacking. Retrieved October 6, 2019 from https://www.ipra.org/news/itle/compulsory-csrindonesia-takes-a-tough-stance-but-clarity-on-definitions-is-lacking.

39.Martinuzzi, A., \& Krumay, B. (2013). The Good, the Bad, and the Successful - How Corporate Social Responsibility Leads to Competitive Advantage and Organizational Transformation. Journal of Change Management, 13(4), 424-443. doi:10.1080/14697017.2013.851953

40.Matthews, L., Hair, J., \& Matthews, R. (2018). PLS-SEM: The Holy Grail for Advanced Analysis. The Marketing Management Journal, 28(1), 1-13.

41. Maulamin, T. (2017). The Implementation of Corporate Social Responsibility (CSR) in Indonesia: A Case Study Approach. European Journal of Research in Social Science, 5(1), 70-81.

42.Mellahi, K., Frynas, J. G., Sun, P., \& Siegel, D. (2015). A Review of the Nonmarket Strategy Literature. Journal of Management, 42(1), 143-173. doi:10.1177/0149206315617241

43.Moir, L. (2001). What do we mean by corporate social responsibility? Corporate Governance: The International Journal of Business in Society, 1(2), 16-22. doi:10.1108/EUM0000000005486

44.Nguyen, P-M, Vo, N. D., Nguyen, N. P., \& Choo, Y. (2020). Corporate Social Responsibilities of Food Processing Companies in Vietnam from Consumer Perspective. Sustainability, 12(1), 71.

45.Peterson, D. K. (2004). The relationship between perceptions of corporate citizenship and organizational commitment. Business and Society, 43. 
46.Podsakoff, P. M., MacKenzie, S. B., Jeong-Yeon, L., \& Podsakoff, N. P. (2003). Common Method Biases in Behavioral Research: A Critical Review of the Literature and Recommended Remedies. Journal of Applied Psychology, 88(5), 879.

47.Ratnawati, Soetjipto, B. E., Murwani, F. D., \& Wahyono, H. (2018). The Role of SMEs' Innovation and Learning Orientation in Mediating the Effect of CSR Programme on SMEs' Performance and Competitive Advantage. Global Business Review, 19(3_suppl), S21-S38. doi:10.1177/0972150918757842

48.Razafindrambinina, D., \& Sabran, A. (2014). The Impact of Strategic Corporate Social Responsibility on Operating Performance: An Investigation Using Data Envelopment Analysis in Indonesia. Journal of Business Studies Quarterly, 6(1), 68-78.

49.Richard, S. A. \& Marilyn, M. H. (2006). Linking strategic practices and organizational performance to Porter's generic strategies. Business Process Management Journal, 12(4), 433-454.

50.Shital, J. (2014). Intertwining CSR with strategy-the way ahead. Corporate Governance: The International Journal of Business in Society, 14(2), 211-219.

51.Sun, L., \& Yu, T. R. (2015). The impact of corporate social responsibility on employee performance and cost. Review of Accounting \& Finance, 14(3), 262-284.

52.Uloli, A. S., Akbar, M., \& Kadir, K. (2019). The Influence of Organizational Culture, and Work Motivation on Work Discipline Employees in Secretariat General of the National Resillience Council. Journal of International Conference Proceedings, 2(3), 1-4.

53.Waagstein, P. R. (2011). The Mandatory Corporate Social Responsibility in Indonesia: Problems and Implications. Journal of Business Ethics, 98(3), 455-466.

54.Wall, T. D., Michie, J., Patterson, M., Wood, S. J. \& et al. (2004). On The Validity Of Subjective Measures Of Company Performance. Personnel Psychology, 57(1), 95-118.

55.Wang, Y., \& Berens, G. (2015). The Impact of Four Types of Corporate Social Performance on Reputation and Financial Performance. Journal of Business Ethics, 131(2), 337-359. doi:10.1007/s10551-014-2280-y

56.Worldbank (2020). Indonesia Overview. Retrieved April 07, 2000 from https://www.worldbank.org/en/country/indonesia/overview.

57.Zhu, Q., Liu, J., \& Lai, K.-h. (2016). Corporate social responsibility practices and performance improvement among Chinese national state-owned enterprises. International Journal of Production Economics, 171, 417-426. 